\title{
The invisible ideological construct of advertising discourse
}

\section{Danielle Barbosa Lins de Almeida}

Doutora em Letras (Língua Inglesa e Literatura Correspondente) pela Universidade Federal de Santa Catarina (UFSC) e professora adjunta do Departamento de Línguas Estrangeiras Modernas (DLEM) do Centro de Ciências Humanas, Letras e Artes (CCHLA) da Universidade Federal da Paraíba (UFPB).

Abstract: In light of the interpretative nature of discourse analysis and within the context of two advertisements of soap - Gessy, dated 1942, and Lux Luxo, dated March 2003 - the main purpose of the present article is to analyse how the discursive practices of advertising discourse allow for the reproduction and maintenance of certain ideological assumptions, such as the ones related to consumerism and gender-based issues.

Keywords: advertising; ideology; gender; consumerism
Resumo: À luz da natureza interpretativa da análise do discurso e dentro do contexto específico de dois anúncios de sabonete-Gessy, de 1942, e Lux Luxo, de 2003 - o principal objetivo do presente artigo é analisar as formas através das quais as práticas discursivas do discurso publicitário reproduzem e perpetuam determinadas ideologias, tais como aquelas relacionadas às questōes de consumo e de gênero.

Palavras-Chave: publicidade; ideologia; gênero, consumo 


\section{.}




\section{Introduction}

Among all transformations that society has experienced over the last decades, one has particularly deserved a more careful look at due to its profound influence on societal behaviour: the role of advertising in modern society.

Advertising has been playing a fundamental role in the construction and maintenance of values and beliefs, enhancing the creation of a new ideology based on the culture of consumerism. As these new ideologies are created by means of spreading mass-media vehicles, new identities are fostered, mainly sustained by the rhetoric of capitalism.

The prevalence of the industry of imagery in modern society sets the ground for the creation of a new way of conceiving visual language as whole texts endowed with a discourse of their own, one that manages to get its message across in an effective manner by mutually associating the visual aspect of language with its verbal form.

The importance of visual language has been contemplated by Fairclough (1989) when he mentions that "a photograph is often as important in getting across the 'message' of a report in a newspaper as the verbal report, and very often visuals and 'verbals' operate in a mutually, reinforcing way which makes them very difficult to disentangle"(p. 28).

Advertising also works as a powerful tool of persuasion, where, in gross terms, the practice of coercion and consent (Fairclough's terms, 1989, p. 33) co-occur through discourse, usually without the consumer's awareness. Both coercion and consent, according to Fairclough (1989), happen by means of ideological power in ways which make certain practices, mainly originated from the 'dominant bloc' - formed by those who compose "an alliance of capitalists and others who see their interests as tied to capital" (Fairclough, 1989, p. 33) - appear commonsensical and universal. In other words, such practices become "naturalised" (Fairclough, 1989, p. 33) and in doing so, Fairclough (ibid.) adds, people - or, in 
the case hereto described, consumers - "often embody assumptions which directly or indirectly embody existing power relations"(ibid.).

The implicit way through which advertising operates reiterates the statement that has generated this essay in that, as pointed out by Fairclough (1989), "ideology is most effective when its workings are least visible" (p. 85).

With a view to illustrating what has been said so far concerning the 'mechanical' internalisation of certain ideological assumptions, I will attempt at discussing how the manifestation of such assumptions occur in advertising, focusing specifically on the analysis of two adverts of soap - Gessy, dated 1942, and Lux Luxo, dated March 2003 both taken from two mainstream media-vehicles, across a period of sixty years. The first advert for the Gessy soap has been taken from the Brazilian newspaper 'O Estado', while the second advert, for the Lux Luxo soap, has been extracted from the Brazilian women's magazine, 'Nova'.

In light of the interpretive nature of discourse analysis and within the context of the referring analysis, my main aim is verifying, in practice, how ideological assumptions can be embedded in media discourse in order to promote further discussion on how the discursive practices of advertising allow for the reproduction and maintenance of unequal power relations.

\section{The Influence of Capitalism in Media Discourse}

For long capitalism has occupied an imperishable position in society. As Fairclough (1989) contends, the economical domain has dominated all possible aspects of modern life, from educational courses to funerals, all of which have been transformed into commodities, which can be easily "bought and sold on the open market in packages, rather like soap powders" (p. 35).

On the top rank of the media-vehicles that help sustaining the force of consumerism is the magazine, which, by making use of a strong elitist rhetoric, caters and distinguishes its members by "constructing a self-contained 
discourse that relies upon an assumed reader identity for its sense of legitimacy" (Fry, 2000, p. 12).

An important notion of power to be explored in media is the one that Fairclough conceives as 'power in' and 'power behind' discourse (p. 43). He relates the "hidden power" of media discourse to the first one, whereby "relations of power are actually exercised and enacted" (ibid.). As for 'power behind discourse', Fairclough (1989) refers to as the types of orders of discourse which are "shaped and constituted by relations of power" (ibid.).

Control in media discourse is something which occurs, most times, indirectly and unconsciously. In this respect, media discourse has a typically undefined nature of power relations, in that, while in "face-to-face interaction participants alternate being the producers and the interpreters of text (...) in media discourse there is (generally) a sharp divide between producers and interpreters", or better stating, between "producers and consumers" (Fairclough, 1989, p. 49).

By nature, the issue of power relations in media discourse is unequal. According to Fairclough (1989), it is the producers who "exercise power over consumers in that they have sole producing rights and can therefore determine what is included and excluded, how events are represented, and (...) even the subject positions of their audiences" (p. 50).

In accordance with Fairclough's (ibid.) statement that ideological assumptions predominantly function at an unconscious level, which facilitates its reproduction and perpetuates its ideological status, one may raise the question of whether media discourse can be regarded as "manipulative" in nature. With this respect to this, Fairclough (ibid.) sustains the argument that indeed, those who he names "power holders" work upon "systematic tendencies" in order to preserve the "pervasive" and "powerful" character of modern media activities since their "relatively homogeneous output" is aimed at an "extremely high level of exposure" (p. 54). 
The discussion about the manipulative character of media discourse can, however, take a further path by associating it with three of the mechanisms proposed by Fairclough (ibid.) to fuller understand how power relations are exercised in discourse. This happens, as he suggests, by means of three distinct processes: (1) first, he says, "practices and discourse types are universally followed and necessarily accepted because no alternative seems conceivable (...)" (p. 75); (2) second, a mechanism which he designates as 'inculcation', which attempts at naturalising "partial and interested practices to facilitate the exercise of power" (ibid.) by power-holders occurs; (3) third, what Fairclough (1989) calls 'communication', which is the final mechanism that leads to "rational communication and debate" (ibid.) happens. From the three mechanisms, Fairclough (ibid.) supports, the most 'salient' one is/the "struggle between communication and inculcation" (ibid.).

\section{The Data}

Following the perspectives heretofore discussed, I may now draw to the analysis of the two adverts involved in supporting the assumptions of the theoretical arguments underlying the present essay.

\section{ADVERT 1: Gessy Soap}

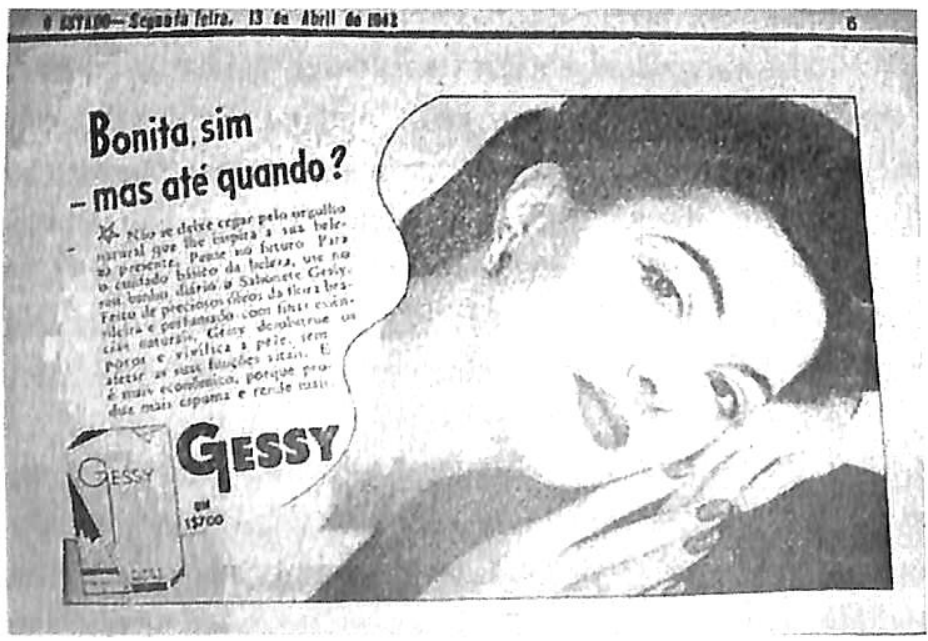


The first ad has been extracted from the no longerexisting Brazilian newspaper 'O Estado' and is dated $13^{\text {th }}$ April 1942. In this advertising, the image of a young and attractive woman resting her face on her hand takes a centre position at the foreground of the picture, and her air of reflectivity while gazing out denotes feelings of preoccupation, insecurity and fear. In doing so, we presuppose that she is thinking upon the problem of facing the inevitability of the ageing process, an interpretation mainly fostered by the following text which accompanies the picture:

Bonita, sim - mas até quando?

Não se deixe cegar pelo orgulho natural que lhe inspira a sua beleza presente. Pense no futuro. Para o cuidado básico, use no seu banho diário o sabonete Gessy. Feito de preciosos óleos da flora brasileira e perfumado com finas essências naturais, Gessy desobstrui os poros e verifica a pele sem afetar as suas funções vitais. E é mais econômico, porque produz mais espuma e rende mais.

The question posed at the headline of the blurb - Beautiful - But for how long? - is threatening in its nature. The statement, followed by an immediate question, acts dialogically in both confirming the current status of one's beauty and challenging its future perpetuation. This invective remark serves as an 'echo' of the reader's apprehensive thought to remind her that she should not rely on the fact that her present beauty will last forever. Thus, in taking up a subject position in the ad, the reader, gives legitimacy to the problem by surrendering to the social pressure of preserving her short-lived beauty.

Bearing this in mind, the ideological status of the assumption present in the referring discourse places an uttermost importance on the immediate control over one's beauty and its consequent preservation, helping naturalise 
and perpetuate the functioning of an ideological identity which the reader is supposed to comply with.

In light of this, the discourse which permeates the advert is suffused with an ideology that prescribes care and caution with a problem that can somehow be under the reader's control, by means of subordination to the consumerist necessity to buy the referring product.

This necessity is personalised in the advert when it takes the form of a 'friendly' advice, while suggesting that the reader should "Think about the future". In doing so, bonds of intimacy are created therefore minimising the vulnerability of the reader towards the fear of the natural consequences of the ageing process.

As a consequence, the reader/consumer is manoeuvred into concealing the signs of ageing at any cost, as a way of commitment to the societal aesthetic standards.

ADVERT 2: Lux Luxo Soap

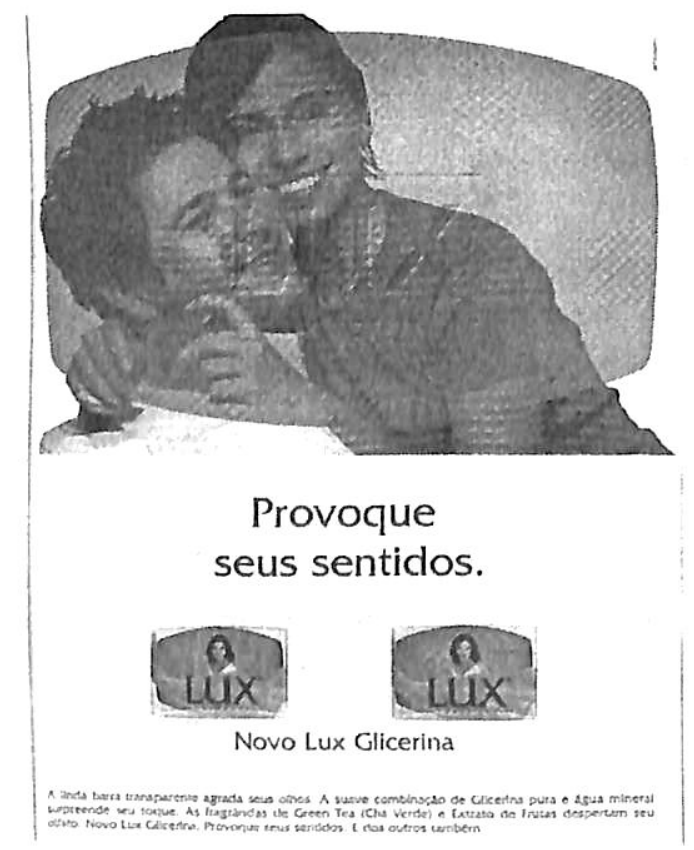

The second advert has been taken from the Brazilian women's magazine 'Nova' and is dated March 2003. 
The magazine 'Nova' focuses on typically female issues such as sexuality, fashion and beauty. The term 'Nova' evokes feelings of innovation - as the name itself presupposes - youth and transgression. 'Nova' describes someone or something who is constantly up-to-date, irrespective of time, and reflects most of the aspirations of its target consumers, the self-conscious $21^{\text {st }}$ century woman.

The advert brings a well-known couple of celebrities hugging each other at the background of the picture, at the same time that an orange, transparent bar of soap emerges into the foreground, creating a sense of immersion. In the central part of the page, black letters read: "Provoque seus Sentidos"

The imperative remark "Provoke your senses" bolsters the notion of sexual appeal, as the act of provoking consists of causing a particular reaction in something for a number of reasons. In the specific case of the ad, the statement has an ambiguous hermeneutic structure, since it encourages both the challenging and consequent 'disturbance' of one's own senses as well as the senses of the opposite sex.

The informative text beneath the image informs:

A linda barra transparente agrada seus olhos. A suave combinação de Glicerina pura e água mineral surpreende seu toque. As fragrâncias de Green Tea (Chá Verde) e Extrato de Ervas despertam seu olfato. Novo Lux Glicerina. Provoque seus sentidos. E dos outros também.

By mentioning three of the five powers of the body - the sight, the touch and the smell - the advert manages to add an ideological effect to the rhetoric of persuasion whereby the media discourse becomes naturalised. Furthermore, the generic notion of femininity that attests to the construction of woman's identity is demarcated by the personification of the selling product whose "pretty transparent bar pleases your eyes", 
"surprises your touch" and "awakes your smell". The somehow transgressing ideology that permeates the referring discourse presupposes an implicit necessity to 'break the conventional rules' by exposing oneself to the beneficial 'dangers' that one can only get by 'provoking one's own senses'. In this sense, the advert reifies its ideological function in making use of its manipulative resources by means of stimulation of one's bodily senses, with a view to the formation of socially-constructed identity which is infused with the consumerist values that capitalist modern society has inculcated.

In drawing an analogy between the first and the second ad, one can realise that the ideology of consumerism has barely modified its rhetoric across a period of over sixty years. What we have witnessed and concluded from the analysis of both ads is the transition from an outwarddictated ideology, whereby the uttermost concern was with the social repercussion of one's own signs of ageing, to a more inward-dictated ideology, in which the sexual connotation plays a stronger role in the construct of one's ideological identity.

\section{Final Considerations}

As Fairclough (1989) mentions, both "subject positions and situation types of dominant discourse types (...) are liable to be naturalised" (p.105) and this is "when ideology becomes common sense". He adds to that by stating that ideology "ceases to be ideology" and starts being ideological effect, "for ideology is truly effective when it is disguised" (p. 107).

The processes of internalisation and naturalisation of common-sense assumptions highlighted by Fairclough (1989) conduct oneself to embody certain socially preestablished ideologies that reinforce both dependency and reproduction of these values, as stated in the assertion that has generated this piece of work.

Indeed, as it has been shown here, one way of doing this is through media vehicles like advertising, that, in being part of our daily life, promote a better 
understanding of the ways whereby the coercive, unconscious and manipulative nature of advertising discourse are revealed. 


\section{References}

FAIRCLOUGH, N. Language and Power. New York: Longman, 1989.

FRY, N. Ideology and Advertising Discourse: an Investigation into the Prescription of Gender Identities. Available online on nbprojects.co.uk/nickfry/Discourse.htm, 2000. 